\title{
Pengaruh Insektisida Nabati Umbi Gadung terhadap Wereng Batang Cokelat (Nillavarpata lugens Stall) Pada Tanaman Padi
}

\author{
Muhidin, Ruswadi Muchtar dan Hasnelly \\ Program Studi Agroteknologi Fakultas Pertanian Universitas Respati Indonesia Jakarta \\ Email: ruswadi_muchtar@yahoo.co.id
}

\begin{abstract}
ABSTRAK
Pengendalian wereng coklat selama ini dilakukan dengan cara konvensional yaitu menggunakan insektisida kimia namun berdampak negatif terhadap lingkungan dan kesehatan. Insektisida nabati merupakan solusi yang tepat untuk mengendalikan hama tanaman. Salah satu insektisida nabati yang dapat digunakan untuk mengendalikan wereng batang coklat adalah umbi gadung. Tujuan penelitian untuk mengetahui efektivitas pestisida nabati umbi gadung terhadap hama wereng coklat pada tanaman padi. Penelitian menggunakan Rancangan Acak Lengkap (RAL) terdiri dari 6 perlakuan dan 4 ulangan sehingga diperoleh 24 unit percobaan. Hasil Penelitian menunjukkan bahwa Insekstisida umbi gadung berpengaruh nyata terhadap mortalitas wereng batang coklat. Dosis insektisida umbi gadung 100 gram/liter menghasilkan mortalitas wereng batang coklat paling tinggi yang dimulai pada 65 jam dan 69 jam setelah aplikasi yaitu 87,90\% dan 89,40\% sedangkan mortalitas wereng batang coklat paling rendah adalah kontrol yaitu kurang dari $7,10 \%$.
\end{abstract}

Kata Kunci: Hama tanaman, Wereng batang coklat, Insektisida nabati, Umbi gadung

\begin{abstract}
Control of brown plant hopper has been done conventionally by using chemical insecticides but it has a negative impact on the environment and health. Vegetable insecticide is the right solution for controlling plant pests. One of the plant-based insecticides that can be used to control brown plant hopper is yam tubers. The purpose of this study was to determine the effectiveness of yam tuber plant-based pesticides on brown plant hopper pests on rice plants. The study used a Completely Randomized Design (CRD) consisting of 6 treatments and 4 replications to obtain 24 experimental units. The results showed that the yam tuber insecticide had a significant effect on the mortality of brown plant hopper. Dosage of 100 gram / liter yam tuber insecticide resulted in the highest mortality of brown plant hopper which started at 65 hours and 69 hours after application, namely $87.90 \%$ and $89.40 \%$ while the lowest mortality of brown plant hopper was control, which was less than $7.10 \%$.
\end{abstract}

Key words: Plant pests, Brown stem slope, Vegetable insecticide, yam Bulbs

\section{PENDAHULUAN}

Serangan hama termasuk kendala utama dalam budidaya tanaman padi, salah satunya adalah wereng batang coklat (Nilaparvata lugens). Hama ini juga merupakan agen pembawa virus (vektor), sehingga dapat mengakibatkan kegagalan panen serta menurunkan produktivitas padi. Wereng batang coklat merusak tanaman padi dengan cara menghisap cairan sel batang tanaman, sehingga menghambat pertumbuhan dan kegagalan panen atau puso [1]. Pada tahun 2010 serangan hama wereng batang cokelat

\section{http://ejournal.urindo.ac.id/index.php/pertanian}

Article History : 
disertai penyakit virus kerdil rumput menyebabkan penurunan produksi padi sebesar 1,1\%. Tahun $2011(65,756$ juta ton gabah kering giling dari poduksi tahun 2010 sebesar 66,469 juta ton gabah kering giling). Luas serangan wereng batang cokelat dari 47.473 hektar pada tahun 2009 menjai 218.060 hektar pada tahun 2011 [2].

Pengendalian hama yang umum dilakukan adalah insektisida kimia dengan frekuensi penyemprotan yang tinggi [3]. Insektisida kimia sebenarnya bisa digunakan untuk membandingkan efektifitasnya jika dibandingkan insektisida nabati. Insektisida kimia yang digunakan sebagai pembanding adalah insektisida yang berfungsi sebagai racun kontak dan pencernaan [4].

Insektisida kimia yang digunakan terus menerus dapat merusak lingkungan bahkan Penggunaan insektisida sintetis secara kontinyu dapat mengakibatkan kerusakan pada lingkungan dan mengganggu kesehatan [5]. Dampak negatif insektisida kimia bagi kesehatan yaitu terganggunya beberapa organ tubuh seperti perut, jantung, ginjal, hati, mata, pencernaan, bahkan bisa berdampak fatal yaitu kematian. Penggunaan insektisida sintesis juga bisa merusak lingkungan seperti kerusakan tanah, air, tumbuhan serta merusak rantai makanan dalam suatu ekosistem.
Solusi atas dampak negatif insektisida kimia adalah mencegah, mengurangi dan tidak menggunakan insektisida kimia namun beralih pada insektisida nabati. Insektisida nabati bisa berasal dari tanaman [6]. Insektisida nabati adalah insektisida yang berasal dari tumbuhan. Pada umumya tumbuhan menghasilkan metabolit sekunder sebagai upaya pertahanan diri terhadap serangan organisme pengganggu tumbuhan seperti hama tanaman.

Insektisida nabati memiliki keunggulan yaitu murah dan mudah dibuat sendiri, relatif aman bagi lingkungan, tidak meracuni tanaman, tidak menyebabkan resistensi terhadap hama, sesuai jika digabungkan dengan metode pengendalian lain serta menghasilkan produk yang sehat karena bebas residu insektisida kimia [7].

Umbi gadung diketahui
mengandung senyawa dioskorin,
diosgenin, dan dioscin. Senyawa tersebut bersifat racun pada manusia karena bisa mengganggu syaraf yaitu pusing dan muntah bagi yang mengkonsumsi umbi tersebut. Senyawa racun tersebut akan didistribusikan ke seluruh organ tanaman sehingga berpotensi digunakan sebagai racun bagi hama tanaman. Ditinjau dari etnobotani maka umbi gadung dapat digunakan sebagai insektisida nabati [8]. Ekstrak umbi gadung efektif digunakan untuk membasmi larva nyamuk [9]. Toksisitas air rebusan umbi gadung 
(Dioscorea hispida Dennst.) yang diberikan kepada mencit galur swiss efektif membunuh tikus [10]. Tujuan penelitian ini mengetahui efektivitas insektisida nabati umbi gadung terhadap hama wereng coklat pada tanaman padi.

\section{METODE}

\section{Bahan dan Alat}

Bahan yang di gunakan adalah umbi gadung, deterjen dan tanaman padi sedangkan alat yang di gunakan adalah kurungan yang terbuat dari kain kasa.

\section{Rancangan Penelitian}

Rancangan penelitian yang digunakan adalah Rancangan Acak Lengkap (RAL) yang terdiri dari 6 perlakuan dengan 4 kali ulangan. Perlakuan tersebut yaitu $A=$ umbi gadung 15 gram/liter, $B=$ umbi gadung 25 gram/liter, $C=$ umbi gadung 50 gram/liter, D = umbi gadung 75 gram/liter, $E=$ umbi gadung 100 gram/liter, dan $F=$ tanpa umbi gadung (kontrol).

\section{Cara Kerja}

\section{Pembuatan Pestisida Nabati}

Umbi gadung ditumbuk kemudian dicampur air dengan perbandingan 100 gram dalam 1 liter air. Larutan tersebut ditambahkan 2 gram deterjen bubuk sebagai pelarut lalu direbus sampai mendidih. Rebusan ekstrak dibiarkan sampai dingin kemudian disaring. Setelah disaring ekstrak insektisida nabati tersebut siap dipakai.

\section{Serangga Uji}

Wereng batang cokelat diambil dari lapangan. kemudian dipelihara pada tanaman padi. Hama dipelihara selama 3 hari agar mampu beradaptasi, kemudian dimasukan ke dalam kurungan uji.

\section{Tanaman Uji}

Varietas padi yang di gunakan adalah varietas ciherang yang merupakan varietas yang di sukai Wereng batang cokelat. Padi direndam di dalam air selama 24 jam, setelah itu benih diangkat dan diperam selama 48 jam sampai berkecambah. Benih yang telah berkecambah disemai di dalam pot tanah. Setelah umur 1 minggu, bibit padi dipindah tanam ke dalam pot yang berisi tanah lumpur dan pupuk lengkap. Setiap pot berisi 3 bibit padi. Setelah tanaman berumur 40 hari tanaman sudah siap untuk di gunakan dalam pengujian.

\section{Aplikasi Pestisida}

Tanaman dikurung dengan kain kasa berwarna putih selama pengujian. Sebanyak 10 ekor wereng batang coklat dimasukan ke dalam kurungan kemudian dilakukan aplikasi insektisida nabati umbi gadung dengan cara disemprotkan satu kali setiap hari.

\section{Parameter Penelitian}

Pengamatan dilakukan dengan menghitung jumlah kematian wereng batang cokelat, setelah aplikasi yaitu 17 jam, 41 jam, 44 jam, 47 jam, 65 jam, dan 69 jam. Rumus mortalitas wereng batang cokelat adalah: 


$$
M=\frac{\mathrm{A}-\mathrm{B}}{\mathrm{A}} \times 100 \%
$$

$M=$ Mortalitas

$A=$ Populasi sebelum aplikasi

$B=$ Populasi setelah aplikasi

\section{HASIL DAN PEMBAHASAN}

Hasil analisis sidik ragam pengaruh insektisida nabati umbi gadung terhadap mortalitas wereng batang coklat pada tanaman padi disajikan pada Tabel 1. Tabel tersebut menunjukkan bahwa insektisida nabati berpengaruh nyata terhadap mortalitas wereng batang coklat pada semua waktu aplikasi. Pemberian insektisida umbi gadung menghasilkan mortalitas wereng batang coklat sangat signifikan lebih tinggi dibandingkan tanpa insektisida umbi gadung. Hal ini disebabkan karena umbi gadung mengandung alkaloid dioscorin saponin dan sapogenin yang merupakan senyawa pahit dan bersifat racun yang dapat menyebabkan kematian nimfa wereng batang cokelat mati [2].

Pada 17 jam setelah aplikasi, diketahui bahwa semakin tinggi dosis insektisida umbi gadung yang diberikan maka semakin tinggi pula mortalitas wereng batang coklat. Perlakuan insektisida umbi gadung 100 gram/liter menghasilkan mortalitas yang paling tinggi yaitu $68,80 \%$ namun berbeda tidak nyata dengan perlakuan 75 gram/liter yaitu 60,50\% namun berbeda nyata dengan perlakuan lainnya. Perlakuan tanpa insektisida umbi gadung menghasilkan mortalitas wereng batang coklat yang paling rendah yaitu $7,10 \%$ dan berbeda nyata dengan perlakuan lainnya.

Pada 41 jam, 44 jam, 47 jam, 65 jam dan 69 jam setelah aplikasi, diketahui bahwa semakin tinggi dosis insektisida umbi gadung yang diberikan maka semakin tinggi pula mortalitas wereng batang coklat. Perlakuan insektisida umbi gadung 100 gram/liter menghasilkan mortalitas yang paling tinggi dan berbeda nyata dengan perlakuan lainnya yaitu $78,80 \%$ pada 41 jam, 44 jam dan 47 jam setelah aplikasi insektisida. Pada 65 jam setelah aplikasi, insektisida umbi gadung menghasilkan mortalitas wereng batang coklat sebesar $87,90 \%$ dan $89,40 \%$ mortalitas wereng batang coklat yang dihasilkan pada 69 jam setelah aplikasi insektisida umbi gadung.

Pada Tabel 1 dapat dilihat pula bahwa secara umum rata-rata mortalitas wereng batang coklat dari 17 jam hingga 69 jam setelah aplikasi insektisida umbi gadung tidak signifikan bahkan terdapat beberapa perlakuan yang menunjukkan mortalitas yang sama dengan waktu aplikasi sebelumnya yaitu perlakuan insektisida umbi gadung 15 gram/liter dan 25 gram/liter pada 41 jam dan 44 jam setelah aplikasi namun terjadi kenaikan persentase mortalitas wereng batang coklat pada 47 jam setelah aplikasi dan terus meningkat hingga pengamatan 69 jam setelah aplikasi. Perlakuan insektisida 


\section{Jurnal IImiah Respati}

umbi gadung 50 gram/liter juga menghasilkan mortalitas wereng batang coklat yang sama pada 44 jam dam 47 jam setelah aplikasi kemudian terus meningkat setelah 65 jam dan 69 jam aplikasi. Perlakuan 75 gram/liter insektisida umbi gadung juga menghasilkan mortalitas wereng batang coklat yang sama pada 44 jam sampai 65 jam setelah aplikasi namun meningkat setelah 69 jam aplikasi. Demikian pula dengan perlakuan inseksitisa 100 gram/liter, menghasilkan mortalitas yang stagnan pada 41 jam hingga 47 jam setelah aplikasi tetapi terus meningkat 65 jam dan 69 jam setelah aplikasi. Namun demikian, pada 69 jam setelah aplikasi insektisida umbi gadung menghasilkan mortalitas wereng batang coklat yang lebih tinggi dibandingkan pada waktu aplikasi lainnya.

Tingkat mortalitas wereng batang coklat disebabkan oleh senyawa dioscorin atau asam sianida ( $\mathrm{HCN})$ yang bersifat racun dalam umbi gadung. Apabila senyawa tersebut terhirup oleh serangga, maka serangga menjadi lumpuh. Senyawa $\mathrm{HCN}$ akan menyerang sistem pernapasan hingga ke sistem saraf dan mengakibatkan kematian secara perlahan-lahan [11].

Tabel 1. Rata-rata mortalitas wereng batang coklat setelah aplikasi insektisida nabati

\begin{tabular}{|c|c|c|c|c|c|c|}
\hline \multirow[b]{2}{*}{ Perlakuan } & \multicolumn{6}{|c|}{ Rata-rata mortalitas setelah aplikasi insektisida (\%) } \\
\hline & 17 jam & 41 jam & 44 jam & 47 jam & 65 jam & 69 jam \\
\hline 15 gram/liter & $40,70 \mathrm{~b}$ & $50,20 \mathrm{~b}$ & $50,20 \mathrm{~b}$ & $54,80 \mathrm{~b}$ & $63,40 \mathrm{~b}$ & $65,50 \mathrm{~b}$ \\
\hline 25 gram/liter & $43,80 \mathrm{~b}$ & $55,20 \mathrm{~b}$ & $55,20 \mathrm{~b}$ & $59,20 \mathrm{~b}$ & $66,60 \mathrm{~b}$ & $66,70 \mathrm{~b}$ \\
\hline 50 gram/liter & $55,60 \mathrm{~b}$ & $67,20 \mathrm{c}$ & $69,00 \mathrm{c}$ & $69,00 \mathrm{c}$ & $70,70 \mathrm{c}$ & $72,60 \mathrm{c}$ \\
\hline 75 gram/liter & $60,50 \mathrm{bc}$ & $69,00 \mathrm{c}$ & $70,70 \mathrm{c}$ & $70,70 \mathrm{c}$ & $70,70 \mathrm{c}$ & $72,60 \mathrm{c}$ \\
\hline 100 gram/liter & $68,80 \mathrm{c}$ & $78,80 \mathrm{~d}$ & $78,80 \mathrm{~d}$ & $78,80 \mathrm{~d}$ & $87,90 \mathrm{~d}$ & $89,40 \mathrm{~d}$ \\
\hline Kontrol & $7,10 a$ & $7,10 a$ & $7,10 a$ & $7,10 a$ & $7,10 a$ & 7,10a \\
\hline
\end{tabular}

Keterangan : angka-angka yang diikuti huruf yang sama pada kolom yang sama berarti tidak berbeda nyata menurut uji BNT 5\%.

Sifat racun pada umbi gadung disebabkan oleh kandungan dioscorin, apabila termakan rasanya seperti tercekik, selain itu umbi gadung mengandung senyawa toksik sehingga dapat dimanfaatkan insektisida nabati [12]. Senyawa dioscorin yang terkandung dalam umbi gadung mempunyai efek insektisida [13]. Sifat racun pada umbi gadung disebabkan oleh senyawa dioscorin, diosgenin, dan dioscin yang dapat menyebabkan gangguan syaraf. Dioscorin juga merupakan racun yang bersifat pembangkit kejang apabila dikonsumsi oleh manusia dan hewan [14]. Seluruh bagian tumbuhan umbi gadung mengandung racun. Karena pada umbi terkandung bahan aktif dioscorin yang menyebabkan kelumpuhan pada sistem saraf [15]. 


\begin{abstract}
Bahan aktif asam sianida memiliki
efek insektisida melalui mekanisme

anticholinesterase. Anticholinesterase

menyebabkan enzim cholinesterase mengalami fosforilasi dan menjadi tidak aktif, sehingga menghambat proses degradasi asetilkolin yang berakibat
\end{abstract}

\section{SIMPULAN}

Insekstisida umbi gadung berpengaruh nyata terhadap mortalitas wereng batang coklat. Dosis insektisida umbi gadung 100 gram/liter menghasilkan mortalitas wereng batang coklat paling tinggi yang dimulai pada 65 jam dan 69 jam setelah aplikasi yaitu $87,90 \%$ dan $89,40 \%$ sedangkan mortalitas wereng batang coklat paling rendah adalah kontrol yaitu kurang dari $7,10 \%$.

\section{DAFTAR PUSTAKA}

[1] Baehaki, S.E. dan Mejaya, M.J. 2014. Wereng Cokelat sebagai Hama Global Bernilai Ekonomi Tinggi dan Strategi Pengendaliannya. Iptek Tanaman Pangan. 9 (1): 1-12.

[2] Naimatul, R.D., K. Slamet, dan S. Prasojo. 2019. Pengaruh Ekstrak Umbi Gadung (Dioscorea hispida Dennts.) terhadap Nimfa Wereng Batang Coklat (Nilapravata lugens Stal.) Sebagai Insektisida. Universitas Muhammadiyah Pekajangan Pekalongan terjadinya akumulasi asetilkolin di celah sinap. Selanjutnya transmisi rangsang meningkat yang menyebabkan otot pernapasan mengalami kontraksi secara terus menerus sehingga terjadi kejang otot pernapasan dan menyebabkan kematian serangga [16].

[3] Sulistyanto. D. 2013. Pengembangan Wilayah Sentra Produksi Pangan Organik yang Murah dengan

Pengelolaan Hama Terpadu Agens Pengendali Hayati untuk Menopang Masterplan Pangan Organik Nasional. Jember: Universitas Jember.

[4] Abadi, H.N., Lyswiana, A., dan Helda, O.R. 2019. Uji Efektivitas Beberapa Pestisida Nabati terhadap Hama Wereng Coklat (Nilaparvata lugens) Pada Tanaman Padi (Oryza Sativa L.). Proteksi Tanaman Tropika 2(02): 115117.

[5] Adriyani, R. 2006. Usaha Pengendalian Pencemaran Lingkungan Akibat Penggunaan Pestisida Pertanian. Surabaya: Universitas Airlangga. Jurnal Kesehatan Lingkungan. 3 (1): 95-106.

[6] Kartoharjo, A. 1988. Kemampuan Beberapa Predator (Laba-Laba Paederus sp., Ophione sp,. Cyrtohius sp., dan Coccinella sp.) dalam Mengurang Kepadatan Wereng Coklat (Nilaparvata Lugens Stall.) pada 
Tanaman Padi. Penelitian Pertanian. 8

(1): 25-31.

[7] Hendayana, D. 2006. Mengenal Tanaman Bahan Pestisida Nabati. Cianjur: PPL Kecamatan Cijati.

[8] Rahayu, S. 2010. Senyawa Aktif Anti Makan dari Umbi Gadung (Dioscorea Hispida Dennts). Jurnal Kimia. 4 (1): 71-78.

[9] Putri,S.H. 2016. Efektivitas Ekstrak Umbi Gadung (Dioscorea Hispida Dents.) dalam Pengendalian Larva Nyamuk. Jurnal Ipteks Terapan.

[10] Aji, T., Ria, E., dan Tunik, S. 2016. Uji Toksisitas Akut Air Rebusan Umbi Gadung (Dioscorea Hispida Dennst.) dan Gambaran Mikroskopis Organ Hepar pada Mencit Galur Swiss Indonesia. Jurnal Farmasi I(I): 22-27.

[11] Apriyani, N., Nopa, N., dan Ivoni, S. 2017. Pengaruh Insektisida Alami Umbi Gadung (Dioscorea Hispida Dennts.) terhadap Mortalitas Kecoa. Program Studi Pendidikan Biologi Jurusan Matematika dan Ilmu Pengetahuan Alam SKIP PGRI Lubuk Linggau, Sumatera Selatan.
[12] Santi, S.R. 2010. Senyawa Aktif Antimakan dari Umbi Gadung (Dioscorea hispida Dennts). Jurnal Kimia. 4(1):71-78.

[13] Utami, S \& Haneda N, F. 2012. Bioaktifitas Ekstrak Umbi Gadung dan Minyak Nyamplung sebagai Pengendali Hama Ulat Kantong (Pteroma plagiophleps Hampson). Jurnal Penelitian Hutan Tanaman. 9(4):209-218

[14] Hasanah, M.2012. Daya Insektisida Alami Kombinasi Perasan Umbi Gadung (Dioscorea hispida Dennst) dan Ekstrak Tembakau (Nicotiana tabacum L). Jurnal Akad Kim. 1(4):166173.

[15] Karmawati, E, \& Kardinan, A. 2012. Pestisida Nabati. Bogor: Pusat Penelitian dan Perkembangan Perkebunan.

[16] Iftita, F. A. 2016. Uji Efektivitas Rendaman Daun Singkong (Manihot utilissima) sebagai Insektisida Terhadap Nyamuk Aedes aegypti Dengan Metode Elektrik Cair. Jurnal Kesehatan Masyarakat (e-journal). $4(2): 20-29$. 